\title{
COMPARATIVE CYTOGENETIC STUDY AMONG THREE FISH SPECIES: AN ANALYSIS FROM A WATER DIVIDE REGION
}

\section{ESTUDO CITOGENÉTICO COMPARATIVO EM TRÊS ESPÉCIES DE PEIXES: UMA ANÁLISE DE UMA REGIÃO DE DIVISOR DE ÁGUAS}

\author{
Maressa Ferreira Neto*, Claudio de Oliveira*, Fausto Foresti*, \\ Viviane Nogaroto**, Mara Cristina de Almeida**, Roberto Ferreira Artoni**, \\ Marcelo Ricardo Vicari**, Orlando Moreira-Filho**** \\ *Departamento de Morfologia, Instituto de Biociências, UNESP, 18618-000, Botucatu \\ (SP), Brazil. \\ ${ }^{* *}$ Departamento de Biologia Estrutural, Molecular e Genética, UEPG, Ponta Grossa (PR), \\ Brazil. \\ *** Departamento de Genética e Evolução, Universidade Federal de São Carlos, Rodovia \\ Washington Luís (SP 310) Km 235, 13565-905, São Carlos, SP, Brazil. E-mail: \\ vicarimr@pq.cnpq.br \\ Recebido para publicação em 15/02/2010 \\ Aceito para publicação em 06/04/2010
}

\begin{abstract}
The aim of the present study was to characterize chromosomal differences between two populations separated in the past for a water divide. Processes of differentiation have been identified in the species studied, being justified by the separation of streams from past for a water divide. Karyotypic data were presented for Astyanax altiparanae, Geophagus brasiliensis and Gymnotus carapo populations of two different river systems of the upper Parana: ribeirão do Pântano (Tietê basin) and ribeirão do Feijão (Mogi Guaçu basin) in the São Carlos region, state of São Paulo. The Astyanax altiparanae, presented a diploid number of $2 \mathrm{n}=50$ chromosomes. The Geophagus brasiliensis diploid numbers was $2 \mathrm{n}=48$ chromosomes and Gymnotus carapo a diploid number of $2 \mathrm{n}=54$ chromosomes. An analysis was made of constitutive heterochromatin by $\mathrm{C}$-banding, detection of nucleolar organizer regions and the technique of Hybridization in situ Fluorescent with probes 18S rDNA and 5S rDNA. These results indicate that the species analysed showed differences of karyotype, showing that each population follows its own evolution, as a result of a restrictive process of gene flow.
\end{abstract}

Keywords: Chromosome differentiation. Citotaxonomy. Fluorescent in situ hybridization. Biogeographic variation.

\section{RESUMO}

O principal objetivo deste estudo foi de caracterizar as diferenças cromossômicas entre duas populações isoladas por um divisor de águas. Processos de diferenciação 
têm sido identificados nas espécies estudadas, os quais são justificados por processos de separação de bacias. Dados cariotípicos foram apresentados para populações de Astyanax altiparanae, Geophagus brasiliensis e Gymnotus carapo de dois diferentes rios do sistema da bacia do Alto Paraná: ribeirão do Pântano (bacia do Tietê) e ribeirão do Feijão (bacia do Mogi Guaçu) na região de São Carlos-SP. Astyanax altiparanae apresentou um $2 \mathrm{n}=50$ cromossomos. No Geophagus brasiliensis o número diplóide foi de $2 \mathrm{n}=48$ e em Gymnotus carapo o 2 n foi de 54 cromossomos. Uma análise dos marcadores de heterocromatina constitutiva, detecção das regiões organizadoras de nucléolo e Hibridação in situ Fluorescente com sondas de rDNA $18 \mathrm{~S}$ e $5 \mathrm{~S}$ também foi realizada. Estes resultados indicam que as espécies analisadas mostraram diferenças cariotípicas, evidenciando que cada população segue seu curso evolutivo como consequência do processo de restrição do fluxo gênico.

Palavras-chave: Diferenciação cromossômica. Citotaxonomia. Hibridação in situ Fluorescente. Variação biogeográfica.

\section{Introduction}

Comparative cytogenetics studies among fish populations from the different river basins, situated in a closelly region of the headwaters barriers has provided to generate hypotheses about karyotype evolution, species dispersal, biogeography, and has wide application in analysis cytotaxonomic (CENTOFANTE et al., 2003; VICARI et al., 2005; 2006; 2008; FERREIRA-NETO et al., 2009; ARTONI et al., 2008; 2009). This type of analysis, when well designed, has shown a greater sensitivity of karyotypic comparison among populations by restricting the study area and factually detecting the possibles differences between populations that have evolved in different river basins, although in a limited geographical area.

The region of São Carlos (São Paulo, Brazil) represents a water divide, where two streams, ribeirão do Feijão e ribeirão do Pântano, were once united, were then separated by a barrier, which served as an impediment to gene flow between species were present, and therefore have been suffering processes of differentiation.

This study describes and compares cytogenetically three species (Astyanax altiparanae, Geophagus brasiliensis and Gymnotus carapo) from the Feijão and Pântano stream, pertaining to Alto Paraná basin, but isolated in adjacent headwaters bariers. The main objective was the karyotype characterization, as well as a cytogenetic comparison among the different samples in order to establish possible evolutionary/biogeographical relationships among them.

\section{Material and Methods}

Cytogenetic data were analyzed in two populations, Feijão and Pântano stream, São Carlos, São Paulo state-Brazil. The species collected were $A$. altiparanae, Geophagus brasiliensis and Gymnotus carapo. All specimens are currently deposited in the ichthyological collection of the Zoology Museum of the Universidade Federal de São Carlos (vouchers numbers 17497, 17521, 17537).

Were analyzed 17 specimens of $A$. altiparanae, eight from the Feijão stream ( 5 males and 3 females) and nine from the Pântano stream (5 males and 4 females). Were collected eight specimens of Geophagus brasiliensis (3 males and 5 females) from the Feijão stream and ten individuals (4 males and 6 females) from the Pântano stream and; Gymnotus carapo were obtained four specimens collected from theFeijão stream (2 males and 2 females) and 16 specimens from the Pântano stream (9 males and 7 females). The procedures were in compliance with the Ethics Committee on Animal Experimentation of the Universidade Estadual de Ponta Grossa (process n ${ }^{\circ}$ : 04741/08). 
Chromosome preparations were obtained from anterior kidney cells using in vivo colchicine treatment (BERTOLLO et al., 1978). Constitutive heterochromatin was visualized by C-banding (SUMNER, 1972). Nucleolar organizing regions (NORs) were detected using silver nitrate staining (Ag-NORs), according to Howell and Black (1980), and fluorescent in situ hybridization (FISH) to locate the 18S rDNA sites on the chromosomes. An 18S rDNA probe (nearly $1,800 \mathrm{bp}$ ) generated by PCR of nuclear DNA from the fish Prochilodus argenteus (HATANAKA; GALETTI Jr., 2004) was used. A 5S rDNA probe from the fish Leporinus elongatus (MARTINS; GALETTI, 1999) was employed to map the 5S rDNA sites on the chromosomes. Both probes were labelled with 14-dATP biotin by nick translation following the manufacturer's instructions (Bionick Labelling System - Invitrogen). The FISH signals were visualized according to Pinkel et al. (1986) and analyzed in an Olympus BX50 epifluorescence microscope. Chromosome images were captured using the software CoolSNAP-Pro (Media Cybernetics).

Nearly 30 metaphases per specimen were analyzed to determine the diploid chromosomze number and the karyotype structure. Chromosomes were classified asm (metacentric), sm(submetacentric), st (subtelocentric), and a (acrocentric), according to Levan et al. (1964).

\section{Results}

The both $A$. altiparanae populations analysed (Feijão and Pântano streams) had a karyotype structure consisting of $2 \mathrm{n}=50$ chromosomes (Fig. 1). These karyotypes were homomorphic, with an absence of morphologically differentiated sex chromosomes. Specimens of the Pântano stream had a fundamental number $\mathrm{FN}=88$, organized in $6 m+28 s m+4 s t+12 a$. The population of the Feijão stream showed $\mathrm{FN}=94$ and kayotypic formulae $6 \mathrm{~m}+30 \mathrm{sm}+8 \mathrm{st}+6$ a (Fig. 1). After C-banding, heterochromatic blocks were observed in the centromeric or pericentromeric regions of all chromosome pairs and in the telomeric regions of some chromosomes with small differences among the analyzed populations (Fig. $1 \mathrm{~b}$ and $\mathrm{d}$, respectivelly).

The Ag-NORs were located terminally on the short arm of a submetacentric chromosome pair in Pântano stream specimens (figure 1b, box), and up to three chromosomes in specimens of ribeirão do Pântano (figure 1d, box). The $18 \mathrm{~S}$ ribosomal sites were located by FISH in the terminal region of the short arm in one subtelocentric pair in Pântano stream specimens (Figure 2a), and in four terminal sites (one pair st in the terminal position of short arm, one submetacentric chromosome position on the short arm and one chromosome in the terminal region of the long arm) in the Feijão stream specimens (Figure 2b). In both $A$. altiparanae populations, the 5S rDNA sites were located in the proximal region of the long arm of the submetacentric pair (Figure $2 \mathrm{c}$ and $2 \mathrm{~d}$ ).

Both Geophagus brasiliensis populations showed $2 \mathrm{n}=48$ chromosomes, $\mathrm{FN}=54$ and similar karyotypic formulae organised in $6 \mathrm{sm}+42 \mathrm{st} / \mathrm{a}$ (Figure 3). C-positive bands located preferentially in centromeric/pericentromeric regions were evidenced in both $G$. brasiliensis populations, with minnors differences among them (Figure $3 \mathrm{~b}$ and 3d).

Figure 1. Karyotypes of the Astyanax altiparanae: $(a, b)$ from the ribeirão do Feijão and, (c, d) from the ribeirão do Pântano. (a, c) Conventionally- Giemsa stained; (b, d) sequentially C-banded chromosomes and Ag-NORs (in box). Bar $=5 \mu \mathrm{m}$.
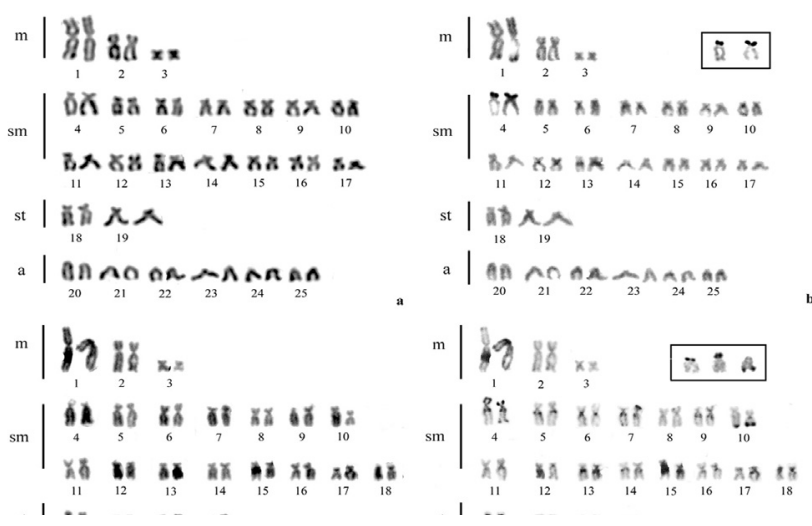
The Ag-NORs and FISH with an 18S rDNA probe, were located in the telomeric region of the short arm of st/a pair 6 for the both G. brasiliensis samples (Figure 3 - box and Figure 4 a, b). Already, the 5S rDNA sites were located in the interstitial region of the long arm of st/a pair (Figure $4 \mathrm{c}, \mathrm{d}$ ).

The Gymnotus carapo showed karyotypic structure composed of the $2 n=54$ chromosomes, $\mathrm{FN}=106$ and, karyotypic formulae organized in $44 m+8 s m+2 s t / a$ in both populations (Fig. $5 \mathrm{a}$ and $5 \mathrm{c}$ ). The C-bands showed all chromosomes contained C-positive heterochromatic segments in the centromeric/pericentromeric region and, no or negligible inter-population differences were observed in both populations (Fig. $5 \mathrm{~b}$ and $5 \mathrm{~d}$ ).

The NORs were situated in the interstitial region of the short arm in the first metacentric pair evidenced by silver nitrate impregnation (Fig. 5 - in boxes) and by FISH with 18S rDNA probing (Fig. 6 $\mathrm{a}$ and $6 \mathrm{~b}$ ). The $5 \mathrm{~S}$ rDNA-positive FISH sites were located in pericentromeric region of the almost all chromosomes of the complement (Fig. $6 \mathrm{c}$ and $6 \mathrm{~d}$ ).

\section{Discussion}

This study associated cytogenetic data, biogeographic aspects, and evolutive biology of fishes species located in the headwaters of two isolated rivers basins (Pântano and Feijão streams) in São Paulo State, Brazil. A great diversity in chromosome number has been found in the genus Astyanax, ranging from $2 \mathrm{n}=36$ in $A$. schubarti to $2 \mathrm{n}=50$ in $A$. scabripinnis, $A$. bimaculatus, A. altiparanae (FERREIRA-NETO et al., 2009; KANTEK et al., 2009) and in Gymnotus genus (MARGARIDO et al., 2007; LACERDA; MAISTRO, 2007; MILHOMEN et al., 2007). In turn, the Cichlidae species like Geophagus and others genus showed a minnor chromosomal diversification, usually restrict to micro alterations in the chromosomes (VICARI et al., 2006; PERAZZO et al., 2010). Thus, the detection of diploid and fundamental number and the implementation of procedures generating molecular markers have been important to evolutionary analysis and cytotaxonomy these fishes.
Figure 2 - Fluorescent in situ hybridization in Astyanax altiparanae: (a, b) $18 \mathrm{~S}$ rDNA probing and $(\mathrm{c}, \mathrm{d})$ 5S rDNA probing in the populations ribeirão do Feijão and Pântano, respectively. Bar $=5 \mu \mathrm{m}$.
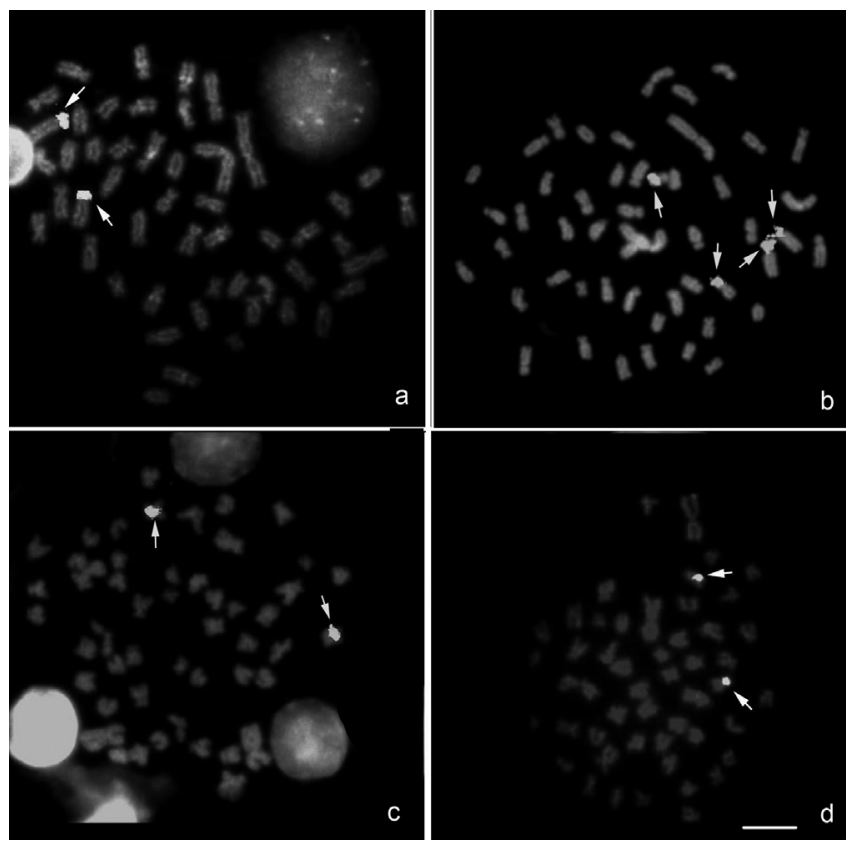

The presence of $2 \mathrm{n}=50$ chromosomes is considered the modal number for Astyanax altiparanae (FERNANDES; MARTINS-SANTOS, 2004; DOMINGUES et al., 2007; FERREIRANETO et al., 2009), as observed in this study too. Studies in A. altiparanae populations of the different basins present small karyotype diversification. Inter-populational karyotypic differences related to chromosomal morphology, especially concerning submetacentric and acrocentric chromosomes, could be observed in the populations from the upper Paraná basin and Iguaçu river (FERREIRA-NETO et al., 2009). Non-robertsonianos events, such as pericentric inversions could be hypotetized in the karyotypic evolution of this species (DOMINGUES et al., 2007). Thus, the karyotypic variability found in this study and among populations may be related to the occupation of different habitats that were geographically isolated, and once occurring genetic variation, these can hardly be shared. 
Figure 3 - Karyotypes of the Geophagus brasiliensis: (a, b) from the ribeirão do Feijão and, (c, d) from the ribeirão do Pântano. $(\mathrm{a}, \mathrm{c})$ ConventionallyGiemsa stained; (b, d) sequentially C-banded chromosomes and Ag-NORs (in box). Bar $=5$ $\mu \mathrm{m}$.
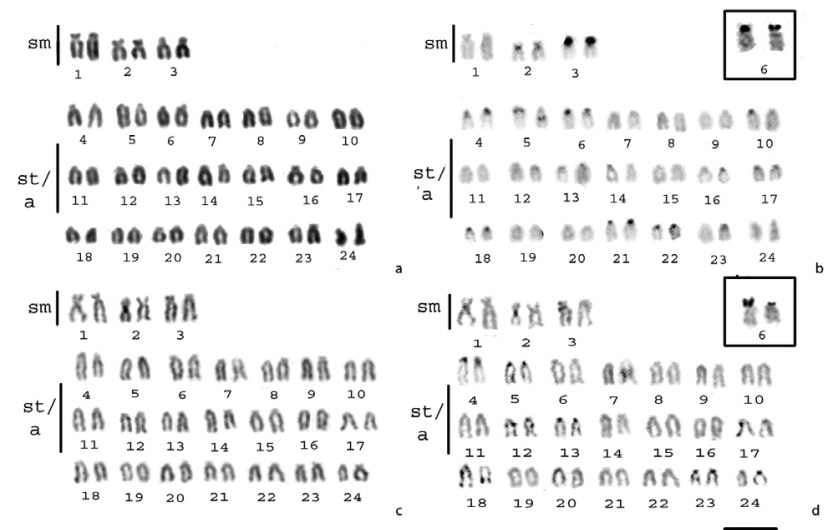

The heterochromatin distribution in $A$. altiparanae shows smalls differences among populations, usually found in pericetromerics or centromeric regions of all chromosome pairs and a few chromosomes in the telomeric region similar to that observed in other populations (FERNANDES; MARTINS-SANTOS, 2004; DOMINGUES et al., 2007; FERREIRA-NETO et al., 2009). The result differ from other species of the genus as $A$. scabripinnis, A. fasciatus and A. janeiroensis, which have a intense diversification of the karyotype in pairs subtelocentric and acrocentric provided by amplification of repetitive DNA sequences AS51 (MANTOVANI et al. 2004; VICARI et al., 2008b; KANTEK et al., 2009). The maintenance of the standard distribution of constitutive heterochromatin in A. altiparanae, along with the great diversity of FN found for the species, support the hypothesis that structural variation could not be explain by amplification of heterochromatic sequences.

The location of Ag-NOR and 18S rDNA sites follow a common trend in the genus Astyanax, with multiple ribosomal sites on chromosomes distributed st/a (MANTOVANI et al., 2000; FERRO et al., 2001; FERNANDES; MARTINS-SANTOS, 2006; VICARI et al., 2008a; 2010). The Ag-NOR and FISH with $18 \mathrm{~S}$ rDNA probe revealed a single pair marked in the Pântano stream population, while the population of ribeirão do Feijão presented multiple telomeric bands in different chromosomes, like studies by other authors in the species (PACHECO et al., 2001; DOMINGUES et al., 2007). The Ag-NORs and 18S rDNA FISH data also revealed variations between both populations of this species probably resulting from the current gene flow restriction.

Figure 4 - Fluorescent in situ hybridization in Geophagus brasiliensis: (a, b) 18S rDNA probing and (c, d) 5S rDNA probing in the populations ribeirão do Feijão and Pântano, respectively. Bar $=5 \mu \mathrm{m}$.
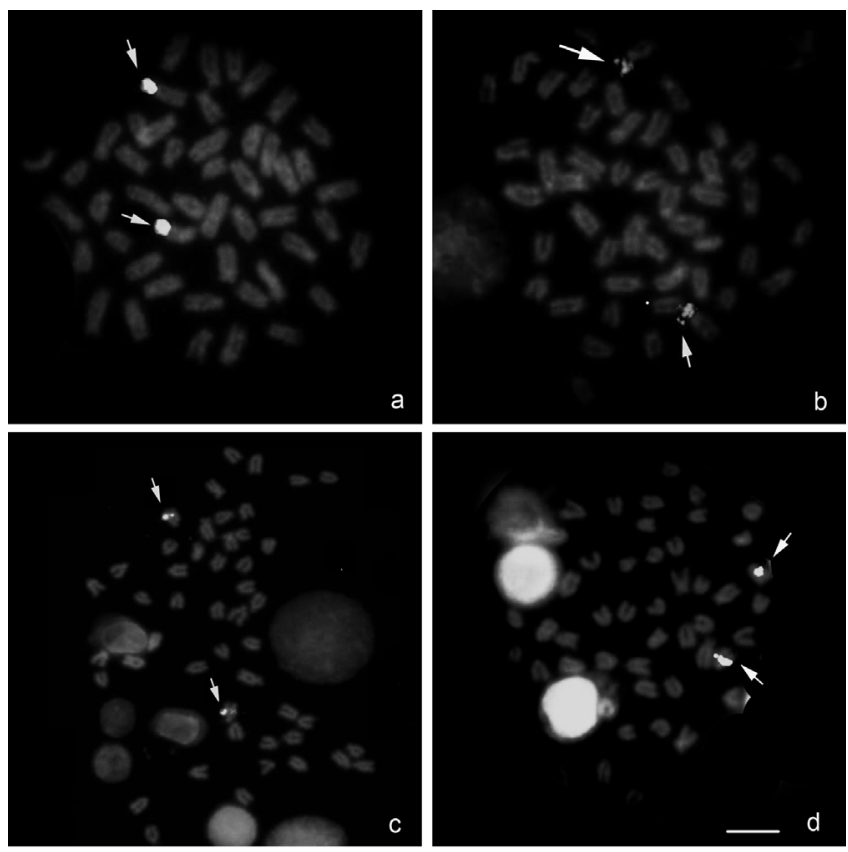

While interpopulation variations occur in the number of sites of the 18S rDNA in A. altiparanae, only one chromosome pair showed sm carrier site of 5S rDNA in the proximal long arm (FERNANDES; MARTINS-SANTOS, 2004, 2006; DOMINGUES et al., 2007; PERES et al., 2008; FERREIRA-NETO et al., 2009; this study). Studies in different species of the genus Astyanax had 5S rDNA sites preserved in two chromosome pairs, one metacentric and one acrocentric, marked in the proximal region (FERRO et al., 2001; ALMEIDA-TOLEDO et al., 2002; MANTOVANI et al., 2005), suggesting a possible synapomorphy for the genus. In this study, both populations show one pair subtelocentric bearing $5 \mathrm{~S}$ rDNA sites in proximal region. Studies in Astyanax sp. and A. janeiroensis, the 5S rDNA site was located in a single pair in the proximal 
region of the long arm, comparable to that found in complex A. scabripinnis (KANTEK et al., 2007; VICARI et al., 2008b, respectively). Mantovani et al. (2000) proposed that sites of 5S rDNA in the proximal position of the long arm to indicate a pattern conserved for these genes in Astyanax. Thus, the chromosomes bearing the 5S rDNA sites are comparable between the populations of $A$. altiparanae studied, however, differ in chromosome morphology and number of sites of those found in other populations of the genus.

Figure 5 - Karyotypes of the Gymnotus carapo: (a, b) from the ribeirão do Feijão and, (c, d) from the ribeirão do Pântano. (a, c) Conventionally- Giemsa stained; (b, d) C-banded chromosomes and Ag-NORs (in box). Bar $=5 \mu \mathrm{m}$.

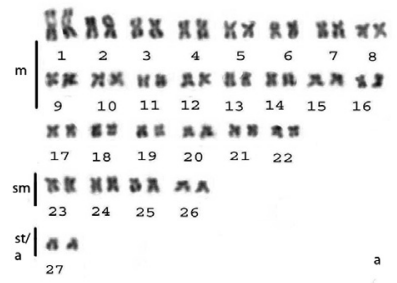

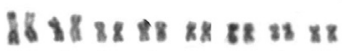

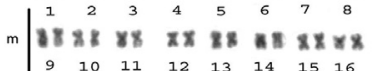

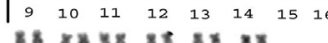
$\begin{array}{llllll}17 & 18 & 19 & 20 & 21 & 22\end{array}$ m 17 a

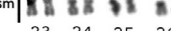
$\begin{array}{llll}23 & 24 & 25 & 26\end{array}$ st/ $/$ \$
a
27

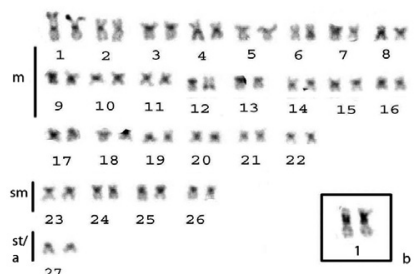

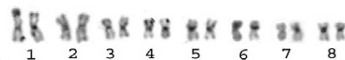

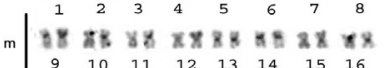
$\begin{array}{cccccccccc}9 & 10 & 11 & 12 & 13 & 14 & 15 & 16\end{array}$ $58 \times 8 \times 8 \geqslant 8 \times 3 \times$ $\begin{array}{llllll}17 & 18 & 19 & 20 & 21 & 22\end{array}$

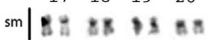

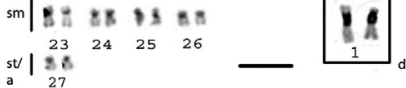

In the Cichlidae family, karyotypic analysis have demonstrated the maintenance of the diploid number in most species. As observed to the most of Neotropical cichlids, the diploid number of 48 chromosomes was constant in both $G$. basiliensis here analyzed, corroborating with the ancestral condition for both Cichlidae and Perciformes (THOMPSON 1979; FELDBERG; BERTOLLO, 1985; MARTINS et al., 1995; VICARI et al., 2006; RONCATI et al., 2007; PERAZZO et al., 2010). However, this diploid number can vary between 32 and 60 chromosomes (FELDBERG et al., 2003) in some cichlids species.

Kullander (1998) based on morphological and molecular, proposed that "Geophagus brasiliensis" seems to be a complex of species. Cytogenetic studies reviewed by Feldberg et al. (2003) corroborate this proposition. Both G. brasiliensis populations here analized had a diploid number of $2 \mathrm{n}=48$ and $\mathrm{FN}=54$. At the same time, several studies in G. brasiliensis show a conserved $2 \mathrm{n}=48$ chromosomes and a variable NF (52 - 56) (PIRES et al., 2008).

Feldberg et al. (2003) demonstrated in Neotropical Cichlidis that constitutive heterochromatin is in the pericentromeric region of most or all chromosomes of the complement. This ditribuition pattern was observed to Feijão and Pântano streams populations. Vicari et al. (2006) showed a peculiar pattern of distribution of heterochromatin in G. brasiliensis river Jaguaiaíva presenting some pairs conspicuous heterochromatic blocks and instersticiais. So, in G. brasiliensis populations minors chromosomal divergences could be atribuited to heterochromatin expansion or exchange how observed in both populations analized.

Figure 6 - Fluorescent in situ hybridization in Gymnotus carapo: $(\mathrm{a}, \mathrm{b}) 18 \mathrm{~S}$ rDNA probing and $(\mathrm{c}, \mathrm{d}) 5 \mathrm{~S}$ rDNA probing in the populations ribeirão do Feijão and Pântano, respectively. Bar $=5 \mu \mathrm{m}$.
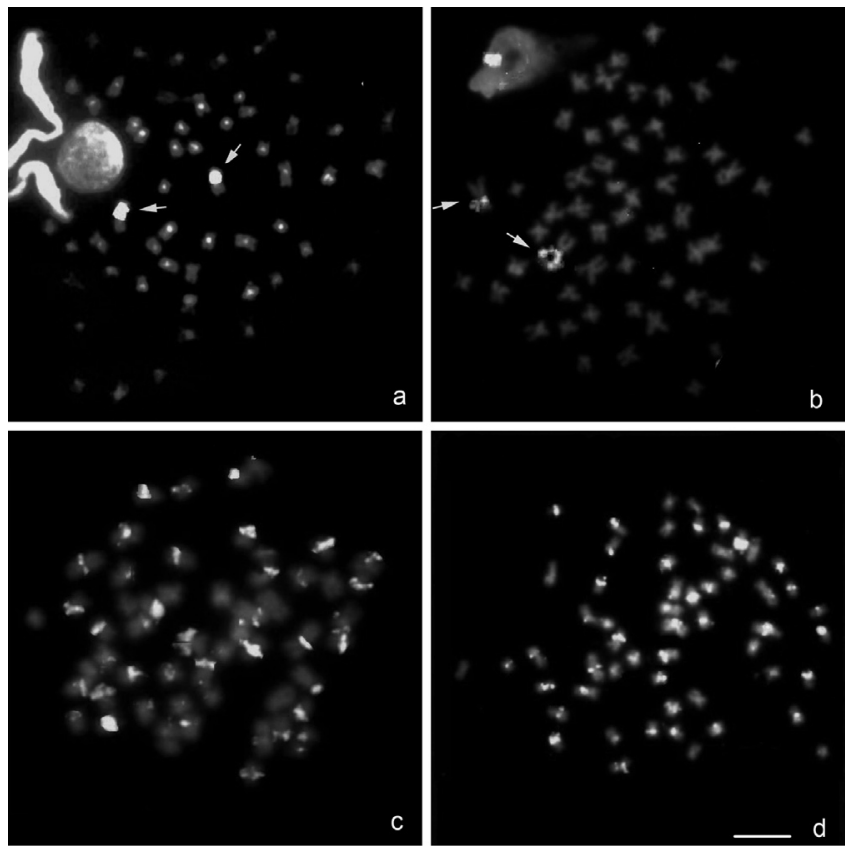

Yet, G. brasiliensis has the characteristic of single NOR located on subtelocentric chromosomes in terminal regions of the short arm (BRUM et al., 1998; FELDBERG et al., 2003; VICARI et al., 
2006; LARISSA et al., 2008). Vicari et al. (2006) analyzed by fluorescence in situ hybridization three different populations of $G$. brasiliensis on the number and location of sites of $18 \mathrm{~S}$ rDNA and $5 \mathrm{~S}$. They found that the chromosomes carrying the $18 \mathrm{~S}$ ribosomal sites were homologous among the species and/or populations, always located on the short arm of chromosome pair st/a. Still, the ribosomal sites among different samples could present a length polymorphism. For the 5S rDNA site the two populations of $G$. brasiliensis in this study exhibited a subtelocentric chromosome pair with interstitial sites of the long arm. These results were the same as found by Vicari et al. (2006) in others populations of this species, being a characteristic well conserved in the group.

According to Oliveira et al. (1988), populations that have lower mobility and number of individuals are more stable in relation to their macro-structure, since the gene flow is lower, thus providing a higher rate of fixation of chromosomal abnormalities. The data obtained confirm that Geophagus brasiliensis has preserved cytogenetic features in relation to other studied populations of this species, and the differences are mainly based on karyotypic formulae, may be the result of chromosomal rearrangements such as pericentric inversions, indicating a possible initial process of speciation.

Amongst the Gymnotiformes are 33 valid species described of Gymnotus and many additional undescribed are known in collections (ALBERT et al., 2005; CRAMPTON et al., 2006). A large variability in chromosome number is found among species and populations of this fish group (ALMEIDA-TOLEDO et al., 2007), which may vary from $2 \mathrm{n}=24$ in Apteronotus albifrons (ALMEIDA-TOLEDO et al., 1981) to $2 \mathrm{n}=54$ for Gymnotus carapo (FORESTI et al., 1984). Data from other studies show that in Gymnotiformes, the karyotype is more divergent than conservative (SILVA; MARGARIDO, 2005).

The reduction in chromosome number among species is an evolutionary trend in the group, with G. carapo presenting $2 \mathrm{n}=54$ chromosomes appear to be basal (FERNANDES-MATIOLI et al., 1998). In this study, specimens of Gymnotus carapo collected in the Feijão and Pântano streams presented the same $2 \mathrm{n}=54$ chromosomes. This possible variation in diploid number in Gymnotus genus and in Gymnotidae can be explained by chromosome fusion events.

The distribution of constitutive heterochromatin in Gymnotiformes is generally characterized by large blocks scattered over almost all chromosomes, with few interpopulational divergences (FERNANDESMATIOLI; ALMEIDA-TOLEDO, 2001; LACERDA; MAISTRO, 2007; MARGARIDO et al., 2007, present study). The FISH with 5S rDNA probe shows the most of the chromosomes signals in the pericentromeric region in both G. carapo populations. These 5S rDNA sites were similar to pericentromeric heterochromatin location. The occurrence of multiple sites of the 5S rDNA in $G$. carapo are possibly due to a family of disperse repetitive DNA like SINE (short interspeced nuclear element) inserted in the NTS (non transcibed spacer) ( that could be evoluated in pseudogenes derived from 5S rDNA, described in others species studies in the Gymnotidae (CLARO, 2008, SILVA, 2010) and in the Erythrinidae family (FERREIRA et al., 2007).

The NOR localization is a good taxonomic tool among Gymnotidae because different species showing $2 \mathrm{n}=54 \mathrm{~m} / \mathrm{sm}$ chromosomes can be distinguished by the NOR chromosome bearing and localization (GALETTI Jr. et al., 1984; FERNANDES-MATIOLI et al., 1998; PEREIRA et al., 2002; LACERDA; MAISTRO, 2007). The location of NORs present in one chromosome pair is a common feature found among the Gymnotiformes (FONTELES et al., 2008). However, in both $G$. carapo populations here analyzed, as well as other populations already studied, had a simple NOR system, located in the interstitial region of the first metacentric pair.

The data of the present study demonstrates the importance of cytogenetic studies, molecular and other morphological comparisons divisor headwaters areas to better understand the evolution of the group, especially when considering the complexity of the Astyanax, Geophagus and Gymnotus genus. Thus, this study compared three 
species from two different headwaters basins (Pântano and Feijão streams), suggesting species maintenance identity, and the minnors differences founded in some karyotypes species suggest each population follows its own evolutionary course with few or no one gene flow.

\section{Acknowledgements}

The authors are grateful to the Instituto Brasileiro do Meio Ambiente e dos Recursos Naturais Renováveis (MMA- IBAMA) by license capture specimens. This study was financed by FAPESP (Fundacão de Amparo à Pesquisa do Estado de São Paulo), CNPq (Conselho Nacional de Desenvolvimento Científico e Tecnológico), CAPES (Coordenação de Aperfeiçoamento de Pessoal de Nível Superior) and the Fundação Araucária (Fundação Araucária de Apoio ao Desenvolvimento Científico e Tecnológico do Estado do Paraná).

\section{REFERENCES}

ALBERT, J. S.; THORSEN, D. H.; LOVEJOY, N. R. Phylogenet systematics and historical biogeography of the Neotropical electric fish Gymnotus (Teleostei: Gymnotidae). Systematics and Biodiversity, v.2, p. 375-417, 2005.

ALMEIDA-TOLEDO, L. F.; DANIEL-SILVA, M. F. Z.; MOYSÉS, C. B.; FORESTI, F. Chromosome variability in Gymnotiformes (Teleostei, Ostariophysi). In: PISANO, E, OZOUF-COSTAZ, C.; FORESTI, F.; KAPOOR, B. D. (Eds.). Fishes cytogenetics Science Publishers, Enfield, 2007, p.16-39.

; DANIEL-SILVA, M. F. Z.; MOIZÉS, C. B.; FONTELES, S. A. B.; LOPES, C. E.; AKAMA, A.; FORESTI, F. Chromosome evolution in fish: sex chromosome variability in Eigenmannia viresnces (Gymntiformes: Sternopygidae). Cytogenetics Genome Research, v.99, p.164-169, 2002.

.; FORESTI, F.; TOLEDO-FILHO, A. S. Constitutive heterocromatins and nucleolus organizer regions in the Knifefish, Apteronotus albifrons. Experientia, v.37, p.953954, 1981.

ARTONI, R. F.; GROSS, M. C.; SCHNEIDER, C.; VICARI, M. R.; ALMEIDA, M. C.; MATOSO, D. A. Epifluorescence and light microscopy evidencing structural and functional polymorphism of ribosomal DNA in fish (Teleostei: Astyanax fasciatus). Micron (Oxford), v. 39, p. 1156-1159, 2008.

ARTONI, R. F.; VICARI, M. R.; ALMEIDA, M. C.; MOREIRA-FILHO, O.; BERTOLLO, L. A. C. Karyotype diversity and fish conservation of southern field from South Brazil. Reviews in fish biology and fisheries, v.19, p.3934012009.

BERTOLlO, L. A. C.; TAKAHASHI, C. S.; MOREIRAFILHO, O. Cytotaxonomic consideration on Hoplias lacerdae (Pisces, Erythrinidae). Brazilian Journal of Genetics, v.1, p.103-120, 1978.

BRUM, M. J. I.; MURATORI, C. F. M. L.; LOPES, P. R. D.; VIANNA, P. R. G. A ictiofauna do sistema lagunar de Marica (RJ). Acta Biology Leopoldensia, v.16, n.2, p. 45-55, 1998.

CENTOFANTE, L.; BERTOLlO, L. A. C.; JUSTI, A. J.; MOREIRA-FILHO, O. Correlation of chromosomal and morphologic characters in two Astyanax species (Teleostei: Characidae). Ichthyological Exploration of Freshwaters, v.14, p.361-368, 2003.

CLARO, F. L. Gymnotus carapo e Gymnotus sylvius (Teleostei: Gymnotidae): uma abordagem citogenéticaMolecular. Dissertação de Mestrado (Universidade de São Paulo), 2008.

CRAMPTON, W. G. R. Evolution of electric signal diversity in Gymnotiform fishes. II. Signal design. In: LADICH, F., COLLIN, S. P., MOLLER, P., KAPOOR B. G. Communication in fishes. Enfield-NH: Science Publishers 2006, p.697-731.

DOMINGUES, M. S.; VICARI, M. R.; ABILHOA, V.; WAMSER, J. P.; CESTARI, M. M.; BERTOLLO, L. A. C.; ALMEIDA, M. C.; ARTONI, R. F. Cytogenetic and comparative morphology of two allopatric populations of Astyanax altiparanae Garutti \& Britski, 2000 (Teleostei, Characidae) from upper rio Paraná basin. Neotropical Ichthyology, v.5, p.37-44, 2007.

FELDBERG, E.; PORTO, J. I. R.; BERTOLlO, L. A. C. Chromosomal changes and adaptation of Cichlid fishes during evolution, 258-308. In: VAL, A. L.; KAPOOR, B. G. Fish adaptations. Science Publishers, INC. New Dehli \& New York, 2003, p.418.

.; BERTOLLO, L. A. C. Karyotypes of 10 species of Neotropical Cichlids (Pisces, Perciformes). Caryologia, v.38, p.257-268, 1985.

FERNANDES-MATIOLI, F. M. C.; MARCHETTO, M. C. N.; ALMEIDA-TOLEDO, L. A.; TOLEDO-FILHO, S. A. High intraspecific karyologycal conservation in four species of Gymnotus (Pisces: Gymnotiformes) from Southeastern Brazilian basins. Caryologia, v.51, p. 221-234, 1998.

M. C.; ALMEIDA-TOLEDO, L. F. A molecular phylogenetic analysis in Gymnotus species (Pisces: 
Gymnotiformes) with inferences on chromosome evolution. Caryologia, v.54, n.1, p.23-30, 2001.

FERNANDES, C. A.; MARTINS-SANTOS, I. C. Cytogenetics studies in two populations of Astyanax altiparanae (Pisces,Characiformes). Hereditas, v.141, p.328-332, 2004.

Mapping of the $18 \mathrm{~S}$ and $5 \mathrm{~S}$ ribosomal RNA genes in Astyanax altiparanae Garutti \& Britski, 2000 (Teleostei, Characidae) from the upper Paraná river Basin, Brazil. Genetics and Molecular Biology, v.29, n.3, p.464-468, 2006

FERREIRA, I. A.; BERTOLLO, L. A. C.; MARTINS, C. Comparative chromosome mapping of 5S rDNA and 5S HindIII repetitive sequences in Erythrinidae fishes (Characiformes) with emphasis on the Hoplias malabaricus 'species complex'. Cytogenetic and Genome Research, v.118, p.78-83, 2007.

FERREIRA NETO, M.; VICARI, M. R.; CAMARGO, E. F.; ARTONI, R. F.; MOREIRA-FILHO, O. Comparative cytogenetics among populations of Astyanax altiparanae (Characiformes, Characidae, Incertae sedis). Genetics and Molecular Biology, v. 32, p. 792-796, 2009.

FERRO, D. M.; MOREIRA-FILHO, O.; BERTOLLO, L. A. C. Nucleolar Organizing regions, $18 \mathrm{~S}$ and 5S rDNA in Astyanax scabripinis (Pisces, Characidae): populations distribution and functional diversity. Genetica, v.110, p.55-62, 2001.

FONTELES, S. B. A.; LOPES, C. E.; AKAMA, A.; FERNANDES, F. M. C.; PORTO-FORESTI, F.; SENHORINI, J. A.; DANIEL-SILVA, M. F. Z.; FORESTI, F.; ALMEIDATOLEDO, L. F. Cytogenetic characterization of the strongly electric Amazonian eel, Electrophorus electricus (Teleostei, Gymnotiformes), from the Brazilian rivers Amazon and Araguaia. Genetics and Molecular Biology, v.31, p.1-9, 2008.

FORESTI, F.; ALMEIDA-TOLEDO, L. F.; TOLEDO-FILHO, A. S. Chromosome studies in Gymnotus carapo and Gymnotus $s p$. (Pisces, Gymnotidae). Caryologia, v.37, p.141-146, 1984.

GALETTI Jr., P. M.; FORESTI, F.; BERTOLLO, L. A. C.; MOREIRA-FILHO, O. Characterization of eight species of Anostomidae (Cypriniformes) fish on the basis of the nucleolar organizing region. Caryologia, v.37, p.401-406, 1984.

HATANAKA, T.; GALLETI Jr., P. M. Mapping of the $18 \mathrm{~S}$ and 5S ribosomal RNA genes in the fish Prochilodus argenteus Agassiz, 1829 (Characiformes, Prochilodontidae). Genetica, v.122, p.239-244, 2004

HOWEL, W. M.; BLACK, D. A. Controlled silver sataining of organizer regions with a protective colloidal developer: a 1-step method. Experientia, v.36, p.1014-1015, 1980.

KANTEK, D. L. Z.; NOLETO, R. B.; FENOCCHIO, A. S.; CESTARI, M. M. Cytotaxonomy, heterochromatic polymorphism and natural triploidy of a species of Astyanax (Pisces, Characidae) endemic to the Iguaçu River Basin.
Brazilian Archives of Biology and Technology, v.50, p.6774, 2007.

; VICARI, M. R.; PERES, W. A. M.; CESTARI, M. M.; ARTONI, R. F.; BERTOLLO, L. A. C.; MOREIRAFILHO, O. Chromosomal location and distribution of As51 satellite DNA in five species of the genus Astyanax (Teleostei, Characidae,). Journal of Fish Biology, v. 75, p. 408-421, 2009

KULLANDER, S. O.; FERREIRA, E. J. G. A new Satanoperca species (Teleostei, Cichlidae) from the Amazon River Basin in Brazil. Cybium, v.12, n.4, p.343-355, 1988.

LACERDA, M. C. V.; MAISTRO, E. L. Cytogenetic Analysis of Three Sympatric Gymnotus Species (Teleostei: Gymnotidae) from the Fundo Stream, MG, Brazil. Cytologia, v.72, p.89-93, 2007.

LARISSA, P. B.; GIULIANO-CAETANO, L.; DIAS, A. N. Karyotype similarities among two populations of Geophagus brasiliensis (Perciformes, Cichlidae) from the Tibagi river basin/PR/Brazil. Caryologia, v.6, n.1/2, p.135-138, 2008.

LEVAN, A.; FREDGA, K.; SANDBERG, A. A. Nomenclature for centromeric positions on chromosomes. Hereditas, v.52, p.202-220, 1964.

MANTOVANI, M.; ABEL, L. D. S.; MESTRINER, C. A.; MOREIRA-FILHO, O. Accentuated polymorphism of heterocromatin and nucleolar organizer regions in Astyanax scabripinnis (Pisces, Characidae): tools for understanding karyotipic evolution. Genetica, v.109, p.161-168, 2000.

.; ABEL, L. D. S.; MESTRINER, C. A.; MOREIRAFILHO, O. Evidence of the differentiated structural arrangement of constitutive heterocromatin between two populations of Astyanax scabripinnis (Pisces, Characidae). Genetics and Molecular Biology, v.27, p.536-542, 2004.

;; ABEL, L. D. S.; MOREIRA-FILHO, O. Conserved $5 \mathrm{~S}$ and variable $45 \mathrm{~S}$ rDNA chromosomal localization revealed by FISH in Astyanax scabripinnis (Pisces, Characidae). Genetica, v.123, p.211-216, 2005.

MARGARIDO, V. P.; BELLAFRONTE E.; MOREIRAFILHO, O. Cytogenetic analysis of three sympatric Gymnotus (Gymnotiformes, Gymnotidae) species verifies invasive species in the Upper Paraná River basin, Brazil. Journal of Fish Biology, v.70, p.155-164, 2007.

MARTINS, C.; PORTELLA-CASTRO, A. L. B.; JULIO Jr., H. F. Chromosome analysis of 5 species of the Cichlidae family (Pisces, Perciformes) from the Paraná river. Cytologia, v.42, p.535-537, 1995.

MARTINS, C.; GALETTI Jr., P. M. Chromosomal localization of $5 \mathrm{~S}$ rDNA genes in Leporinus Fish (Anostomidae, Characiformes). Chromosome Research, v.7, p.363-367, 1999.

MILHOMEM, S. S. R.; PIECZARKA, J. C.; CRAMPTON, W. R.; SOUZA, A. C. P.; CARVALHO, JR.; J. R.; NAGAMACHI, C. Y. Differences in karyotype between two sympatric species 
of Gymnotus (Gymnotiformes:Gymnotidae) from the eastern amazon of Brazil. Zootaxa, v.1397, p. 55-62, 2007.

OLIVEIRA, C.; ALMEIDA-TOLEDO, L. F.; FORESTI, F.; BRITSKI, H. A.; TOLEDO-FILHO, S. A. Chromosome formulae of neotropical freswater fishes. Brazilian Journal of Genetics, v.11, p.577-624, 1988.

PACHECO, R. B.; GIULIANO-CAETANO, L.; DIAS, A. L. Cytotypes and multiple NORs in an Astyanax altiparanae population (Pisces, Tetragonopterinae). Chromosome Science, v.5, p.109-114, 2001.

PERAZZO, G. X.; NOLETO, R. B.; VICARI, M. R.; MACHADO, P. C.; GAVA, A.; CESTARI, M. M. Chromosomal studies in Crenicichla lepidota and Australoheros facetus (Cichlidae, Perciformes) from extreme Southern Brazil. Review in Fish Biology and Fisheries, (in press). Doi: 10.1007/s11160-010-9170-x

PERES, W. A. M.; BERTOLLO, L. A. C.; MOREIRA-FILHO, O. Physical mapping of the $18 \mathrm{~S}$ and $5 \mathrm{~S}$ ribosomal genes in nine Characidae species (Teleostei, Characiformes). Genetics and Molecular Biology, v.31, p.222-226, 2008.

PEREIRA M. A.; OLIVEIRA, C.; FORESTI, F.; MAISTRO, E. L. Cytogenetic and Nucleolar Content Analysis in Anostomidae Fishes from the Sapucai River, Minas Gerais State, Brazil. Cytologia, v.67, p.289-296, 2002.

PINKEL, D.; STRAUME, T.; GRAY, J. W. Cytogenetic analysis using quantitative, high-sensitivity, fluorescence hybridization. Proc Natl Acad Sci, USA, v.83, p.2934-2938, 1986.

PIRES, L. B.; GIULIANO-CAETANO, L.; DIAS, A. L. Karyotype similarities among two populations of Geophagus brasiliensis (Perciformes, Cichlidae) from the Tibagi river basin/PR/Brazil. Caryologia, v.61, p.135-138, 2008.

RONCATI, H. A.; PASTORI, M. C.; FENOCHIO, A. S. Cytogenetic studies and evolutive considerations on fishes of the family Cichlidae (Perciformes) from Parana River (Argentina). Cytologia, v.72, p.379-384, 2007.

SILVA, E. B.; MARGARIDO, V. P. An X1X1X2X2/X1X2Y multiple sex chromosome system in a new species of the genus Gymnotus (Pisces, Gymnotiformes). Enviromental Biology of Fishes, v.73, p.293-297, 2005.

SILVA, M. Evolução da diferenciação cromossômica entre os sexos no gênero Gymnotus (Gymnotiformes, Gymnotidae). Programa de Pós-Graduação em Biologia Evolutiva (dissertação de mestrado). Universidade Estadual de Ponta Grossa, Ponta Grossa, 2009.

SUMNER, A. T. A simple technique for demonstrating centromeric heterocromatin. Experimental Cell Research, v.75, p.304-306, 1972.
THOMPSON, K. W. Cytotaxonomy of 4 species of Neotropical Cichlidae. Copeia, v.1979, p.679-691, 1979.

VICARI, M. R.; ARTONI, R. F.; BERTOLlO, L. A. C. Comparative cytogenetics of Hoplias malabaricus (Pisces, Erythrinidae): A population analysis in adjacent hydrographic basins. Genetics and Molecular Biology, v.28, p.103-110, 2005.

; ARTONI, R. F.; MOREIRA-FILHO, O.; BERTOLLO, L. A. C. Basic and Molecular Cytogenetics in freswater Cichlidae (Osteichthyes, Perciformes). Karyotypic conservationism and divergence. Caryologia, v.59, n.3, p.260-266, 2006.

; NOLETO, R. B.; ARTONI, R. F.; MOREIRAFILHO, O.; BERTOLLO, L. A. C. Comparative cytogenetics among species of the Astyanax scabripinnis complex. Evolutionary and biogeographical inferences. Genetics and Molecular Biology, v. 31, p.173 - 179, 2008a.

; ARTONI, R. F.; MOREIRA-FILHO, O.; BERTOLLO, L. A. C. Co-localization of repetitive DNAs and silencing of major rDNA genes. A case report in the fish, Astyanax janeiroensis. Cytogenetic and Genome Research, v.122, p.67-72, $2008 \mathrm{~b}$.

.; NOGAROTO, V.; NOLETO, R. B.; CESTARI, M. M.; CIOFFI, M. B.; ALMEIDA, M. C.; MOREIRA-FILHO, O.; BERTOLLO, L. A. C.; ARTONI, R. F. Satellite DNA and chromosomes in Neotropical fishes: Methods, applications and perspectives. Journal of Fish Biology, v.76, p.10941116, 2010. 